\title{
Correlation between Head Computed Tomography Scan, Pre-operative Blood Lactate, and Pre-operative Glucose Level in Acute Traumatic Subdural Hematoma
}

\author{
Jefri Henky, ${ }^{1}$ Ahmad Faried ${ }^{2}$ \\ ${ }^{1}$ Department of Neurosurgery, Faculty Medicine of Baiturrahmah University/Semen Padang Hospital \\ Padang, Indonesia, ${ }^{2}$ Department of Neurosurgery Faculty of Medicine Universitas Padjadjaran/ \\ Dr. Hasan Sadikin General Hospital Bandung, Indonesia
}

\begin{abstract}
Acute traumatic subdural hematoma (SDH) is a focal brain injury resulting in alteration of cerebral perfusion and glucose metabolism, which would also results in hyperglicemia-induced-hyperlactatemia. A cross-sectional study was performed to analyze acute traumatic SDH patients by head CT scan and observe the effect on pre-operative blood lactate and blood glucose levels in 40 acute traumatic SDH patients at Dr. Hasan Sadikin Hospital Bandung, Indonesia during the period of July-September 2013. Somers' D correlation were used in the analysis with a p-value of $\leq 0.05$ considered as significant with $95 \%$ confidence interval. The mean values of pre-operative blood lactate and blood glucose levels were $3.16 \pm 1.49 \mathrm{mmol} / \mathrm{L}$ and $155.85 \pm 32.95 \mathrm{mg} / \mathrm{dL}$, respectively with a strong positive correlation between the hematoma thickness and the increase in blood lactate $(r=0.656 ; p=0.021)$ and a moderate positive correlation with increased blood glucose $(r=0.556 ; p=0.025)$. In addition, the compressed cistern also had a very weak positive correlation with increase in blood lactate $(r=0.156 ; p=0.043)$ and very weak positive correlation with increase in blood glucose $(r=0.139 ; \mathrm{p}=0.056)$ while the midline shift had a weak positive correlation with increased blood lactate $(\mathrm{r}=0.353 ; \mathrm{p}=0.041)$ and a weak positive correlation with increased blood glucose $(r=0.333 ; p=0.046)$. In conclusion, increased hematoma thickness, compressed cistern, and midline shift seen on head CT scan correlate with increasing blood lactate and glucose levels in acute traumatic SDH. Head CT scan, blood lactate level, and blood glucose level can be considered as one of the routine examinations to determine acute traumatic SDH severity at the macroscopic and cellular level.
\end{abstract}

Keywords: Acute traumatic subdural hematoma, blood lactate, blood glucose, head computer tomography scan

\section{Hubungan CT Scan Kepala dengan Laktat Darah Preoperatif dan Kadar Glukosa pada Hematoma Subdural Traumatik Akut}

\begin{abstract}
Abstrak
Hematoma subdural traumatik akut (SDH), cedera otak fokal yang mengakibatkan perubahan perfusi otak dan metabolisme glukosa; mekanisme ini menyebabkan hiperglikemia-hiperlaktatemia. Studi potong lintang dilakukan untuk menganalisis pasien SDH traumatik akut yang dilakukan pemeriksaan CT scan kepala serta mengobservasi hubungannya dengan kadar laktat dan kadar glukosa darah pre-operasi pada 40 pasien SDH traumatik akut di Rumah Sakit Dr. Hasan Sadikin Bandung, Juli-September 2013. Menggunakan Somers' D dan p-value $\leq 0.05$ dianggap signifikan dengan CI 95\%. Rerata kadar laktat darah pre-operasi 3.16 $\pm 1.49 \mathrm{mmol} / \mathrm{L}$ dan glukosa darah pre-operasi $155.85 \pm 32.95 \mathrm{mg} / \mathrm{dL}$. Uji korelasi Somers’ D menunjukkan ketebalan hematoma berkorelasi positif kuat dengan peningkatan laktat darah $(\mathrm{r}=0.656 ; \mathrm{p}=0.021)$ dan berkorelasi positif sedang dengan peningkatan glukosa darah $(\mathrm{r}=0,556 ; \mathrm{p}=0,025)$, kompresi sisterna berkorelasi positif sangat lemah dengan peningkatan laktat darah $(r=0.156 ; p=0.043)$ dan korelasi positif sangat lemah dengan peningkatan glukosa darah $(r=0.139 ; p=0.056)$, pergeseran garis tengah memiliki korelasi positif lemah dengan peningkatan laktat darah $(r=0.353 ; p=0.041)$ dan korelasi positif lemah dengan peningkatan glukosa darah $(\mathrm{r}=0.333 ; \mathrm{p}=0.046)$. Peningkatan ketebalan SDH, kompresi sisterna dan pergeseran garis tengah berkorelasi dengan peningkatan kadar laktat dan glukosa darah pada SDH traumatik akut. CT scan kepala, laktat darah dan glukosa darah dijadikan salah satu pemeriksaan rutin menentukan keparahan SDH traumatik akut pada tingkat makroskopik dan sel.
\end{abstract}

Kata kunci: Hematoma subdural traumatis akut, laktat darah, glukosa darah, pemindaian tomografi komputer kepala

Corresponding Author: Jefri Henky, Department of Neurosurgery, Faculty Medicine of Baiturrahmah University/Semen Padang Hospital Padang, Jl. By Pass KM 15, Kota Padang, West Sumatra, Indonesia,, Email: neurosurg_henky@yahoo.co.id 


\section{Introduction}

Traumatic brain injury (TBI) is one of the causes of death and disability in humans in productive age of $\leq 45$ years. The International Mission for Prognosis and Clinical Trial (IMPACT) data presented that deaths and disabilities in the productive age group are dominated by males with a ratio of 3: 1 . Studies suggest that the incidence of TBI is between 18 and 250 per 100,000 persons per year. Men and people living in socially and economically deprived areas, usually young adults and the elderly, are the high-risk groups for TBI. ${ }^{1}$

In providing health care and treatment, neurosurgeons are always challenged when dealing with patients experiencing TBI because they have to work meticulously to be able to reduce the risk of disability and death. This is due to the fact that the already high disability rate (25-35\%) and mortality rate may become even higher if the neurosurgeon does not pay intense attention to the management of TBI. In addition, it is crucial that the hospital has adequate care facilities and that drugs are continuously developed to help the recovery process of postTBI patients. The actual burden of TBI and its sequelae appears to be underestimated, owing to incomplete capture of data especially in low- and middle-income countries (LMICs). ${ }^{2}$ Nevertheless, the LMICs face almost three times more cases of TBI proportionally than the highincome countries (HICs).

One of the focal brain injuries that cause neurological deficits with sequela, and even death, after TBI is acute traumatic hematoma or SDH. Based on the Traumatic Coma Data Bank (TDCB), the incidence of traumatic SDH is approximately $24 \%$ of all TBI incidents, with $21 \%$ manifesting as severe head injuries, $11 \%$ as minor head injuries, and $68 \%$ as moderate head injuries. The mortality rate among all intracranial focal lesions is quite high, approximately $50-60 \%$, with several outcome predictive factors, such as age, duration of occurrence, accompanying trauma, the Glasgow coma scale (GCS) value, thickness of hematoma, narrow cisterns, midline shift, brain edema/contusions and the presence of subarachnoid bleeding (SAB).,3,

The pathogenesis of cellular injury due to acute traumatic SDH is the duration of congestion of the superficial veins in cerebral hemispheres and the extraordinary activation of excitatory neurotransmitter receptors and glutamatergic $\mathrm{N}$-methyl-D-aspartate (NMDA) receptors, which can cause neuronal damages such as ischemic necrosis that occurs due to thin compression of the hematoma, with the hematoma takes the shape of a thin crescent, or short period compression, or due to contusions and resulting edema $^{4,5}$

Under extreme conditions such as acute traumatic SDH, the aerobic metabolism is compromised by decreased oxygen and glucose supplies, mitochondrial damages, or increased excitatory neurotransmitter release that result in increased accumulation of intracellular lactate. Lactate production can occur in all body tissues, such as in the skeletal muscle, brain, red blood cells, and kidneys. The level of lactate in normal humans can decline rapidly with an average rate of $320 \mathrm{mmol} / \mathrm{L} / \mathrm{hr}$. This decline is a product of metabolism by the liver and the process of lactate reconstruction back to pyruvate. The lactate level is maintained in a basal state of $<1$ $\mathrm{mmol} / \mathrm{L}$ in venous and arterial blood. ${ }^{6}$

Delivery of glucose to the brain is facilitated by the glucose transporter 3 (GLUT 3), which is independent of insulin actions but is dependent on blood delivery or adequate perfusion. In acute traumatic SDH and brain ischemia, glucose transporters and glucose metabolism processes are disrupted, and there is an increase in lactate uptake by neurons in the brain due to increased energy requirements, which then leads to hyperglycemia-induced-hyperlactatemia. This process will cause a systemic hyperglycemic reaction as a result of the high level of lactate caused by hyperglycolysis and hypoglycemia in the brain tissue. ${ }^{6-8}$

On head computer tomography (CT) scan, an acute traumatic SDH is described as a hyperdense, crescent-shaped lesion which lies between the dura mater and the parenchyma of the brain. They are often surrounded by hypodense lesions, which are edematous lesions, in the brain parenchyma with narrowing of the groove and compression of the gyrus in the cerebral cortex. These conditions result in a shift in the midline, or midline shift, and a narrowing of the cisterns. The head CT scan is clinically associated with the outcome of acute traumatic SDH and is also used as an indication for surgery. ${ }^{9}$

Head CT scan indicative of acute traumatic SDH surgery are characterized by hematoma thickness of $>10 \mathrm{~mm}$ and hematoma volume, midline shift of $>5 \mathrm{~mm}$ and the patency of the basal cistern. Previous studies showed that older patients, a midline shift of $>5 \mathrm{~mm}$, and an emphasis on basal cisterns correlate with a mortality of rate of $>70-80 \%$. Patients with hematoma thickness of $<10 \mathrm{~mm}$ have been 
reported to have a mortality rate of $10 \%$ whereas patients with hematoma thickness of $>30 \mathrm{~mm}$ had been reported to have a mortality rate of $90 \% .{ }^{9}$ Furthermore, the time from TBI to surgery may not be as important as the time from clinical deterioration or onset of cerebral herniation to surgery. The literature supports the statement that the time span from clinical deterioration to operative treatment of an SDH significantly links to outcome.

\section{Methods}

This study was a cross-sectional observational analytic study to analyze acute traumatic SDH patients by head CT scan and observe the effect of traumatic SDH on pre-operative blood lactate and blood glucose levels. This study was conducted at Dr. Hasan Sadikin Hospital (RSHS), Bandung, Indonesia during the period of July to September 2013 under the ethical clearance number 273/UN6.C2.1.2/KEPK/PN/2013. With reference to the correlation analysis formula, 40 patients was included as the subjects. The inclusion criteria used for participation were adult acute traumatic SDH patients ( $\geq 18$ years) who met the indication for surgery whose families gave the permission to participate in the study. Blood lactate and blood glucose levels from the patients were measured prior to acute traumatic SDH.

The exclusion criteria for this study are acute traumatic SDH patients whose injuries were accompanied by focal extradural lesions, such as epidural hematoma (EDH); intradural focal lesions, such as intracerebral hematoma (ICH); diffuse axonal injury lesions; multiple extradural injuries; failure or disturbance of respiration and systemic circulation since the onset of trauma; systemic disease before trauma, such as diabetes, liver, lung, heart, kidney disease; and known to receive conservative therapy from other hospitals using osmotic diuretics and corticosteroids. The independent variables of this study were SDH thickness, cistern compression, and midline shift as seen on head CT scan while the dependent variables were blood lactate level and blood glucose level based on the blood test results of acute traumatic SDH patients.

Data were analyzed using the SPSS for windows ver. 20. Data of subject characteristics were displayed descriptively and the data distribution was assessed using the Kolmogorov Smirnov test. Somers' D correlation test was used to test the correlation between the preoperative lactate and blood glucose levels and each independent variable. Table 1 below lists the reference values for correlation (r), significance (p) and direction of correlation. The set value of confidence interval (CI) in this study was $95 \%$.

\section{Results}

In this study, 40 acute traumatic SDH patients with the mean age of $44.73 \pm 19.76$ years were studied. The percentage of male patients were $62.5 \%$, with a male to female ratio of $2: 1$. The mean operating time interval in this study was $17.08 \pm 11.86$ hours. Approximately $67.5 \%$ of acute traumatic SDH patients were admitted to the hospital with moderate head injury (GCS 9-13), followed by severe head injury (GCS 3-8,

Table 1 Interpretation of Correlation Test Results Based on Correlation Strength (r), Significance (p), and Correlation Direction

\begin{tabular}{|c|c|c|}
\hline Parameter & Value & Interpretation \\
\hline Correlation Strength (r) & $\begin{array}{l}0.0 \text { to }<0.2 \\
0.2 \text { to }<0.4 \\
0.4 \text { to }<0.6 \\
0.6 \text { to }<0.8 \\
0.8 \text { to } 1\end{array}$ & $\begin{array}{l}\text { Very weak } \\
\text { Weak } \\
\text { Medium } \\
\text { Strong } \\
\text { Very strong }\end{array}$ \\
\hline Significance (p) & $\begin{array}{l}\mathrm{p}<0.05 \\
\mathrm{p}>0.05\end{array}$ & $\begin{array}{l}\text { There is a significant correlation between the two } \\
\text { variables tested } \\
\text { There was no significant correlation between the two } \\
\text { variables tested }\end{array}$ \\
\hline Correlation Direction & $\begin{array}{l}+ \text { (positive) } \\
- \text { (negative) }\end{array}$ & $\begin{array}{l}\text { Unidirectional, the greater the value of one variable is, the } \\
\text { greater the value of the other variables } \\
\text { In opposite directions, the greater the value of one } \\
\text { variable is, the smaller the value of the other variables }\end{array}$ \\
\hline
\end{tabular}


J Henky \& A Faried: Correlation between Head Computed Tomography Scan, Pre-operative Blood Lactate, and Pre-operative Glucose Level in Acute Traumatic Subdural Hematoma

Table 2 Patient Characteristics

\begin{tabular}{lc}
\hline \multicolumn{1}{c}{ Characteristics } & Statistical Value \\
\hline Age & $44.73 \pm 19.76(18-82)$ \\
Sex & \\
$\quad$ Male & $25 / 40(62.50 \%)$ \\
$\quad$ Female & $15 / 40(37.50 \%)$ \\
Surgical interval (hours) & $17.08 \pm 11.86(2-48)$ \\
Glasgow coma scale during admission & $1 / 40(2.50 \%)$ \\
Mild head injury (GCS 14-15) & $27 / 40(67.50 \%)$ \\
Moderate head injury (GCS 9-13) & $12 / 40(30.00 \%)$ \\
Severe head injury (GCS 3-8) & \\
SDH thickness according to head CT scan & $20 / 40(50.00 \%)$ \\
$\quad<15$ mm & $20 / 40(50.00 \%)$ \\
15-20 mm & \\
Cistern compression according to head CT scan & \\
$\quad$ Compressed & $25 / 40(62.50 \%)$ \\
$\quad$ Not Compressed & $15 / 40(37.50 \%)$ \\
Midline shift according to head CT scan & \\
$\quad>5$ mm & \\
$\quad<$ mm & $32 / 40(80.00 \%)$ \\
Preoperative hemoglobin level (g/dL) & $8 / 40(20.00 \%)$ \\
Preoperative blood glucose level (mg/dL) & $12.47 \pm 1.71(9.20-15.40)$ \\
\hline
\end{tabular}

$30 \%$ ) and minor head injury (GCS 14-15, 2.5\%) (Table 2).

Based on the results of the head CT scan, $50 \%$ of patients with acute traumatic SDH experienced a hematoma thickness of $<15 \mathrm{~mm}$ and $50 \%$ had a thickness of $15-20 \mathrm{~mm}$. Approximately $62.5 \%$ showed emphasis on the basal cistern and $80 \%$ presented a midline shift image of $>5 \mathrm{~mm}$ (Table 2).

The laboratory results were as follows: the mean preoperative hemoglobin $(\mathrm{Hb})$ level was $12.47 \pm 1.71 \mathrm{~g} / \mathrm{dl}$, while the mean pre-operative blood lactate level in acute traumatic SDH patients was $3.16 \pm 1.49 \mathrm{mmol} / \mathrm{L}$ and the mean level of pre-operative blood glucose in acute traumatic SDH patients was $155.85 \pm 32.95 \mathrm{mg} /$ dl. Data normality test was carried out on all numerical variables with results are presented in Table 2.

Almost all variables in this study were found to have a $p$ value of $>0.05$, except for the operating time interval variable which was not normally distributed with a $\mathrm{p}$ value of $<0.0001$. The Kolmogorov Smirnov test showed that the age variable age, preoperative $\mathrm{Hb}$ level, preoperative blood lactate level, and pre-operative

Table 3 Correlation between SDH Thickness Based on Head CT Scan and Preoperative Blood Lactate and Blood Glucose Levels

\begin{tabular}{|c|c|c|c|c|c|c|}
\hline \multicolumn{2}{|c|}{$\begin{array}{l}\text { Variable } \\
<15 \mathrm{~mm}\end{array}$} & \multicolumn{2}{|c|}{$\begin{array}{c}\text { SDH Thickness } \\
15-20 \mathrm{~mm}\end{array}$} & \multirow{2}{*}{$\begin{array}{c}\text { Total } \\
8\end{array}$} & \multirow{3}{*}{$\begin{array}{c}\begin{array}{c}\text { Correlation } \\
\text { (r) }\end{array} \\
0.656\end{array}$} & \multirow{3}{*}{$\begin{array}{l}\text { Sig. } \\
\text { (p) }\end{array}$} \\
\hline \multirow{2}{*}{$\begin{array}{l}\text { Pre-operative blood } \\
\text { lactate level }\end{array}$} & Normal & 3 & 5 & & & \\
\hline & Hyperlactatemia & 17 & 15 & 32 & & \\
\hline \multirow{2}{*}{$\begin{array}{l}\text { Pre-operative blood } \\
\text { glucose level }\end{array}$} & Normal & 4 & 0 & 4 & \multirow{2}{*}{0.556} & \multirow{2}{*}{0.025} \\
\hline & Hyperglycemia & 16 & 20 & 36 & & \\
\hline
\end{tabular}

\footnotetext{
* Somers'd Correlation Test
} 
J Henky \& A Faried: Correlation between Head Computed Tomography Scan, Pre-operative Blood Lactate, and Pre-operative Glucose Level in Acute Traumatic Subdural Hematoma

Table 4 Correlation between Cisternal Compression Based on Head CT Scan and Preoperative Blood Lactate and Blood Glucose Levels

\begin{tabular}{|c|c|c|c|c|c|c|}
\hline \multirow{2}{*}{\multicolumn{2}{|c|}{$\begin{array}{c}\text { Variable } \\
\text { Compressed }\end{array}$}} & \multirow{2}{*}{\multicolumn{2}{|c|}{$\begin{array}{c}\text { Cistern compression } \\
\text { Not compressed }\end{array}$}} & \multirow{3}{*}{$\begin{array}{c}\text { Total } \\
8\end{array}$} & \multirow{4}{*}{$\begin{array}{c}\begin{array}{c}\text { Correlation } \\
\text { (r) }\end{array} \\
0.156\end{array}$} & \multirow{4}{*}{$\begin{array}{c}\text { Sig. } \\
\text { (p) }\end{array}$} \\
\hline & & & & & & \\
\hline \multirow{2}{*}{$\begin{array}{l}\text { Pre-operative blood } \\
\text { lactate level }\end{array}$} & Normal & 4 & 4 & & & \\
\hline & Hyperlactatemia & 21 & 11 & 32 & & \\
\hline \multirow{2}{*}{$\begin{array}{l}\text { Pre-operative blood } \\
\text { glucose level }\end{array}$} & Normal & 2 & 2 & 4 & \multirow{2}{*}{0.139} & \multirow{2}{*}{0.056} \\
\hline & Hyperglycemia & 23 & 13 & 36 & & \\
\hline
\end{tabular}

* Somers'd Correlation Test

Table 5 Midline Shift Correlation Based on Head CT Scan with Pre-operative Blood Lactate and Blood Glucose Levels

\begin{tabular}{|c|c|c|c|c|c|c|}
\hline \multirow{2}{*}{\multicolumn{2}{|c|}{$\begin{array}{l}\text { Variable } \\
>5 \mathrm{~mm}\end{array}$}} & \multirow{2}{*}{\multicolumn{2}{|c|}{$\frac{\text { Midline Shift }}{<5 \mathrm{~mm}}$}} & \multirow{3}{*}{$\begin{array}{c}\text { Total } \\
8\end{array}$} & \multirow{4}{*}{$\begin{array}{c}\begin{array}{c}\text { Correlation } \\
\text { (r) }\end{array} \\
0.353\end{array}$} & \multirow{4}{*}{$\begin{array}{r}\text { Sig. } \\
\text { (p) }\end{array}$} \\
\hline & & & & & & \\
\hline \multirow{2}{*}{$\begin{array}{l}\text { Pre-operative blood } \\
\text { lactate level }\end{array}$} & Normal & 6 & 2 & & & \\
\hline & Hyperlactatemia & 26 & 6 & 32 & & \\
\hline \multirow{2}{*}{$\begin{array}{l}\text { Pre-operative blood } \\
\text { glucose level }\end{array}$} & Normal & 2 & 2 & 4 & 0.333 & 0.046 \\
\hline & Hyperglycemia & 30 & 6 & 36 & & \\
\hline
\end{tabular}

* Somers'd Correlation Test

blood glucose level were normally distributed $(\mathrm{p}=0.098, \mathrm{p}=0.163, \mathrm{p}=0.158, \mathrm{p}=0.055$, respectively).

The SDH thickness correlation, in Somers' D correlation test, to the preoperative blood lactate level was significant $(p<0.05)$ with a correlation coefficient of 0.656 , indicating that there was a strong positive correlation between the SDH thickness and the preoperative blood lactate level. The correlation of SDH thickness to the preoperative blood glucose level was also significant $(p<0.05)$ with a correlation value of 0.556 , indicating a moderate positive correlation between the SDH thickness and the preoperative blood glucose level (Table 3).

The correlation of cistern compression in the Somers' D correlation test to pre-operative blood lactate levels was significant $(\mathrm{p}<0.05)$ with a correlation value of 0.156 , indicating a very weak positive correlation between the cistern compression and the pre-operative blood lactate level. The correlation of cistern compression to pre-operative blood glucose levels was not significant ( $p>0.05)$ with a correlation value of 0.139 , indicating a very weak positive correlation between the cistern compression and the preoperative blood glucose level (Table 4).

The midline shift correlation in Somers' D correlation test to the preoperative blood lactate level was significant $(\mathrm{p}<0.05)$ with a correlation value of 0.353 , indicating a weak positive correlation between the midline shift and the preoperative blood lactate level. The midline shift correlation to the preoperative blood

Table 6 Correlation of Pre-operative Blood Lactate Levels with Preoperative Blood Glucose Levels

\begin{tabular}{llccccc}
\hline \multirow{2}{*}{$\begin{array}{l}\text { Variable } \\
\text { Normal }\end{array}$} & \multicolumn{2}{c}{$\begin{array}{c}\text { Pre-operative Blood Lactate } \\
\text { Level }\end{array}$} & Total & $\begin{array}{c}\text { Correlation } \\
\text { (r) }\end{array}$ & $\begin{array}{c}\text { Sig. } \\
\text { (p) }\end{array}$ \\
\cline { 2 - 5 } & Normal & 1 & 3 & 4 & 0.568 & 0.037 \\
\hline $\begin{array}{l}\text { Pre-operative blood } \\
\text { glucose level }\end{array}$ & Hyperglycemia & 7 & 29 & 36 & \\
\hline
\end{tabular}

* Somers'd Correlation Test 
glucose level was also significant $(\mathrm{p}<0.05)$ with a correlation value of 0.333 , indicating a weak positive correlation between the midline shift and the preoperative blood glucose level (Table 5).

The correlation of the preoperative blood lactate level in the Somers' D correlation test to the preoperative blood glucose level was significant $(\mathrm{p}<0.05)$ with a correlation value of 0.568 , indicating a moderate positive correlation between the pre-operative blood lactate level and the pre-operative blood glucose level (Table 6).

\section{Discussion}

The mean age of acute traumatic SDH patients in this study is similar to the TBI epidemiological data reported by IMPACT in a previous literature that stated TBI as one of the causes of death and disability in productive age populations $(\leq 45$ years). One of the contributing factors to this is the fact that the productive age population have more outdoor activities, such as work and sports, which influence the accident rate. Age of acute traumatic SDH patients is one of the factors influencing the outcome. It is stated in the literature that older patients has a mortality rate that is four times higher, or worse outcomes, than younger patients. 1,4,10,11

In this study, the male gender contributes approximately $62.5 \%$ with a male to female ratio of $2: 1$, which is slightly lower than the ratio in the literature, stating that TBI is more often found in males with male to female ratio of 3:1 in women. This is thought to be caused by the fact that more men do heavy works outside home and use vehicles more frequently than women. ${ }^{1,12}$

Approximately $67.5 \%$ of acute traumatic SDH patients in this study were admitted with moderate head injury (GCS 9-13), followed by severe (GCS 3-8) and minor (GCS 14-15) head injury (30\% and $2.5 \%$, respectively). This is almost similar to the TDCB data that $68 \%$ of patients with acute traumatic SDH have a manifestation of moderate head injury while $21 \%$ and $11 \%$ have the manifestation of severe head injury and minor head injury. The GCS value has a strong relationship with the outcome and recovery of patient's neurological functions. ${ }^{6,7,11}$

The surgery time interval is also a confounding variable that is taken into account in this study. It was found that the average operating time interval was $17.08+11.86$ hours. The average surgery time interval of this study was $>8$ hours, more than the golden hour, but had not reached the silver day ( $<24$ hours). ${ }^{13}$

On the CT scan of the head, $50 \%$ subjects experienced a hematoma thickness of $<15 \mathrm{~mm}$ while another $50 \%$ had a hematoma thickness of $15-20 \mathrm{~mm}$. In terms of basal cisterns emphasis, about $62.5 \%$ of the subjects were demonstrated to have an emphasis on basal cisterns, while the remaining $37.5 \%$ without did not. This can be interpreted that the hematoma thickness in acute traumatic SDH can cause a focal effect on brain tissues in the form of brain superficial veins congestion and impaired brain perfusion, enabling it to progress into cerebral edema which results in the compression of the basal cistern that indicates an elevated ICP. 4,9,11,14

The focal effect of hematoma and cerebral edema can be seen in this study in the form of a midline shift of $>5 \mathrm{~mm}$, which was seen in $80 \%$ of the subjects, and a midline shift of $<5 \mathrm{~mm}$ as seen in $20 \%$ of the subjects. According to several studies, all aspects of the CT scan of the head are indirect factors that determine the outcome of patients with acute traumatic SDH. 4,8,9,14

From blood laboratory examination, the mean preoperative hemoglobin level in this study was $12.47+1.71 \mathrm{~g} / \mathrm{dL}$. Mean hemoglobin levels in this study were still within normal limits, with a reference value of 12.1-17.6 g/dL for male patients and 11.7-16.2 g/dL for female patients. ${ }^{15}$

The mean preoperative blood lactate level for acute traumatic SDH patients was $3.16+1.49$ $\mathrm{mmol} / \mathrm{L}$. The mean value of the blood lactate level in this study exceeded the normal limit of the blood lactate level in adult patients of 0.9-1.7 $\mathrm{mmol} / \mathrm{L}$. The elevation in the blood lactate level is in line with the results of studies reported by Kawamata et al. and Cureton et al. that the blood lactate level could increase shortly after TBI and increase about $23.7 \%$ from the baseline, which will then back to normal in 24-36 hours if the annoyance and damage are resolved. ${ }^{13,16}$

In addition, the mean preoperative blood glucose level in patients with acute traumatic SDH was $155.85+32.95 \mathrm{mg} / \mathrm{dl}$. The mean value of the blood glucose level in this study exceeds the normal limit of adult patients of 70-115 $\mathrm{mg} / \mathrm{dl}$. This increase in the blood glucose levels is in accordance with the findings in a previous study by Magnoni et al., stating that the systemic hyperglycemia is a response to glucose metabolic disorders and increased levels of lactate in brain tissue. $^{6-8,15}$

The results of the correlation analysis between GCS at the time of hospitalization 
and the preoperative blood lactate level is negatively very weak. Likewise, the results of the GCS correlation analysis on admission on the preoperative blood glucose level presented a very weak negative correlation. The results of this correlation analysis reinforce the assumption that the smaller the GCS value is or the lower the consciousness of the acute traumatic SDH patient is, the higher the blood lactate level and the blood glucose level of the acute traumatic SDH patient; thus, the GCS of the acute traumatic SDH patients can reflect an increase in the blood lactate level and blood glucose level due to the emerging hyperglycolysis and glucose metabolic disorders. $5,7,8,17,18$

The correlation analysis on the operation time interval with preoperative blood lactate level showed a very weak positive correlation. Furthermore, the correlation analysis of the operation time interval with the preoperative blood glucose level also showed a weak positive correlation. This means the longer the operation time interval is, the higher the blood lactate level and blood glucose level of the acute traumatic SDH patients because the length of the operation time interval in acute traumatic SDH patients illustrates the how long the focal damage to the brain is sustained, the duration of impaired brain tissue perfusion, the duration of cerebral edema, and the duration of glucose metabolic disorders and hyperglycolysis, which then lead to the production of large amounts of lactate. ${ }^{6-8,17}$

The correlation between the SDH hematoma thickness and preoperative blood lactate level presented a strong positive correlation. Meanwhile, the correlation between SDH thickness and preoperative blood glucose level showed a moderate (moderate) positive correlation. These results indicate that the thicker the SDH hematoma is, the higher the blood lactate and blood glucose levels because the thickness of the hematoma will reflect the magnitude of focal emphasis on the brain tissue of the acute traumatic SDH patient. 4,5,9,11,14

The correlation of cistern compression with the preoperative blood lactate level showed a very weak positive correlation. While the correlation of cistern compression with preoperative blood glucose level was not significant and presented a very weak positive correlation. Although the correlation of cisternal compression with the blood lactate and blood glucose levels is very weak and insignificant, it is understood that the cistern compression is a continuation effect of focal suppression and brain edema that occurs over a long period of time. This reason is reinforced because $62.5 \%$ of cases of the cisternal compression are comparable to $50 \%$ of cases of hematoma thickness of $15-20 \mathrm{~mm}$, meaning that a large proportion of study subjects experienced severe brain edema that compressed the basal cisterns. The effects of edema can be seen in the increase in blood lactate and blood glucose levels in acute traumatic SDH patients. ${ }^{4,5,9,11,14}$

Regarding the focal suppression of hematoma and brain edema discussed above, it appears that the midline shift correlation with preoperative blood lactate levels shows a weak positive correlation and the midline shift correlation with preoperative blood glucose levels also shows a weak positive correlation. This means that the greater the midline shift on CT scan of the head of an acute traumatic SDH patient is, the higher the blood lactate and blood glucose levels of the patient. This is a combination of the effects of hematoma suppression and brain edema, which aggravates hyperglycolysis and impaired glucose metabolism in brain tissue after acute traumatic SDH.. ${ }^{4,5,9,11,14}$

The laboratory diagnostic component that was also considered as a confounding variable in this study was the hemoglobin level. The correlation between the hemoglobin level and the preoperative blood lactate level demonstrated a very weak negative correlation. Meanwhile, the correlation between the preoperative hemoglobin level and the preoperative blood glucose level was weak negative. The correlation between these two variables means that the lower the hemoglobin level is (anemia), the higher the blood lactate and blood glucose levels. This correlation is not a causal relationship due to the effect of hematoma suppression or brain edema, but it reflects the hemoglobin disruption that will reduce oxygen and glucose supply to brain tissue and may interfere with glucose metabolism and glycolysis. ${ }^{6-8,17}$

The correlation of the preoperative blood lactate level and preoperative blood glucose levels was moderately positive. This indicates that the higher the blood lactate level of the acute traumatic SDH patient is, the higher the blood glucose level of the acute traumatic SDH patient and vice versa.

In association with the mechanism of increased lactate due to acute traumatic SDH, this correlation analysis is acceptable because the pathophysiology of hyperlactatemia caused hyperglycolysis and impaired glucose metabolism in brain tissue will include systemic induction of glucose. This response is known in the literature as the hyperglycemia- 
induced-hyperlactatemia and has been proven biochemically and statistically in this study of acute traumatic SDH patients. ${ }^{19,20}$

Not all variables were analyzed in this current study because the sample size and time was limited. Hence, it is recognized that there are many biases that may influence the results of the study. In addition, technical factors such as the blood sampling to check lactate and glucose levels must also be considered. In this study, all blood samples of acute traumatic SDH patients were taken from the venous blood because it was easier to obtain, faster, and ethical for the patient.

The literature also proves that the venous blood lactate has no significant difference with the arterial blood lactate; however, the best blood sample for examining blood lactate levels is from the venous blood sample. Meanwhile, the blood sample for checking blood glucose levels should be the arterial blood because the venous blood glucose is estimated to be $10 \%$ higher than in the arterial blood glucose. ${ }^{15}$

Another bias has been identified from the inclusion criteria and exclusion criteria, as there is an attempt to have homogeneous sample, which is proven based on the results of the normality test that shows all variables to be normally distributed. Therefore, the results of this study can be used as inputs for considerations, guidelines, and references to explain acute traumatic SDH patient's condition, treatment, and estimated outcomes. It is recommended to examine the blood lactate and blood glucose levels as routine checks in acute traumatic SDH patients.

In conclusion, the thicker SDH demonstrates more compressed cisterns and greater the midline shift on the CT scan of the head, as well as higher blood lactate and blood glucose levels in acute traumatic SDH patients. CT scan of the head, blood lactate level, and blood glucose level can be considered to be included as the routine tests in determining the macroscopic and cellular severity of acute traumatic SDH.

\section{References}

1. Popescu C, Anghelescu A, Daia C, Onose G. Actual data on epidemiological evolution and prevention endeavours regarding traumatic brain injury. J Med Life. 2015;8(3):272-7.

2. Hutchinson PJ, Kolias AG, Tajsic T, Adeleye A, Aklilu AT, Apriawan T, et al. Consensus statement from the International Consensus Meeting on the role of decompressive craniectomy in the management of traumatic brain injury consensus statement. Acta Neurochir (Wien). 2019;161(7):1261-74.

3. Robertson C, Castilla L. Critical care management of traumatic brain injury. In: Winn H, Berger M, Dacey R, editors. Youmans and Winn neurological surgery. Philadelphia: Elsevier Saunders; 2011. p. 3397-423.

4. Shahlaie K, Zweinenberg-Lee M, Muizelaar J. Clinical pathophysiology of traumatic brain injury. In: Winn H, Berger M, Dacey $\mathrm{R}$, editors. Youmans and Winn Neurological Surgery. Philadelphia: Elsevier Saunders 2011. p. 3362-79.

5. MckeeAC, Daneshvar DH.Theneuropathology of traumatic brain injury. Handb Clin Neurol. 2015;127:45-66.

6. Clausen F, Hillered L, Gustafsson J. Cerebral glucose metabolism after traumatic brain injury in the rat studied by 13C-glucose and microdialysis. Acta Neurochir (Wien). 2011;153:653-8.

7. Magnoni S, Tedesco C, Carbonara M, Pluderi M, Colombo A, Stocchetti N. Relationship between systemic glucose and cerebral glucose is preserved in patients with severe traumatic brain injury, but glucose delivery to the brain may become limited when oxidative metabolism is impaired: Implications for glycemic control. Crit Care Med. 2012;40(6):1785-91.

8. Meierhans R, Brandi G, Fasshauer M, Sommerfeld J, Schüpbach R, Béchir M, et al. Arterial lactate above $2 \mathrm{mM}$ is associated with increased brain lactate and decreased brain glucose in patients with severe traumatic brain injury. Minerva Anestesiol. 2012;78(2):185-93.

9. Zacko J, Harris L, Bullock R. Surgical management of traumatic brain injury. In: Winn $\mathrm{H}$, Burger $\mathrm{M}$, Dacey $\mathrm{R}$, editors. Youmans and Winn Neurological Surgery. Philadelphia: Elsevier Saunders; 2011. p. 3424-3252.

10. Leitgeb J, Mauritz W, Brazinova A, Janciak I, Majdan M, Wilbacher I, et al. Outcome after severe brain trauma due to acute subdural hematoma: Clinical article. J Neurosurg. 2012;117(2):324-33.

11. Sharma R, Rocha E, Pasi M, Lee H, Patel A, Singhal AB. Subdural hematoma: predictors of outcome and a score to guide surgical decision-making. J Stroke Cerebrovasc Dis. 2020;29(11):105180.

12. Bullock M, Hovda D. Introduction to traumatic brain injury. In: Winn $\mathrm{H}$, Berger 
M, Dacey R, editors. Youmans and Winn neurological surgery. Philadelphia: Elsevier Saunders; 2011. p. 3267-9.

13. Grevfors N, Lindblad C, Nelson DW, Svensson M, Thelin EP, Rubenson Wahlin R. Delayed neurosurgical intervention in traumatic brain injury patients referred from primary hospitals is not associated with an unfavorable outcome. Front Neurol. 2021;11:610192.

14. Jiang C, Cao J, Williamson C, Farzaneh N, Rajajee V, Gryak J, Najarian K, et al. Midline shift vs. mid-surface shift: correlation with outcome of traumatic brain injuries. Proceedings (IEEE Int Conf Bioinformatics Biomed). 2019;2019:1083-6.

15. Fischbach F, Dunning MB. A Manual of Laboratory and Diagnostic Tests. 9th ed. Lippincott Williams and Wilkins; 2015. p. 53-173.

16. Romeu-Mejia R, Giza CC, Goldman JT.
Concussion pathophysiology and injury biomechanics. Curr Rev Musculoskelet Med. 2019;12(2):105-16.

17. Yu LY, Pei Y. Insulin neuroprotection and the mechanisms. Chin Med J (Engl). 2015;128(7):976-81.

18. Hansen T, Jensen $T$, Clausen $B$, et al. Natural RNA circles function as efficient microRNA sponges. Nature. 2013;495:384-8.

19. Zhou J, Burns MP, Huynh L, Villapol S, Taub DD, Saavedra JM, et al. Temporal changes in cortical and hippocampal expression of genes important for brain glucose metabolism following controlled cortical impact injury in mice. Front Endocrinol (Lausanne). 2017;8:231.

20. Brooks GA. The tortuous path of lactate shuttle discovery: From cinders and boards to the lab and ICU. J Sport Heal Sci. 2020;9(5):446-60. 